\title{
HUBUNGAN KUTU DOMPOLAN DYSMICOCCUS BREVIPES (CKLL.) (HOMOPTERA : PSEUDOCOCCIDAE) DAN SEMUT API SOLENOPSIS SP. (HYMENOPTERA: FORMICIDAE) PADA DUA CARA BERTANAM NENAS
}

\author{
Rosma Hasibuan ${ }^{1}$
}

\begin{abstract}
Association of mealybug, Dysmicoccus brevipes (Ckll.) (Homoptera: Pseudococcidae) and fire ant, Solenopsis sp. (Hymenoptera: Formicidae) on two pineapple-planting patterns. A pineapple mealybug, Dysmicoccus brevipes (Ckll.) (Homoptera: Pseudococcidae) is an important insect pest in major pineapple growing areas. Its feeding activity causes damage on the pineapple plants and it can also transmit pineapple wilt virus. The mealybugs are often found in association with fire ants, Solenopsis sp. (Hymenoptera: Formicidae) that provide protection in exchange for the sweet honeydew liquid. The field study was conducted to determine the close association between mealybugs and fire ants on two plant row spacing (single and double row spacing) four different plant stages (3, 7, 11, and 17 months after planting). The results indicated that there was a significant correlation between the mealybugs and the fire ant on two pineapple-planting patterns, particularly on late growth periods (11, and 17 months after planting). In this field study, population of mealybugs on double row spacing were more abundant (ranging from 0 to $25.67 \mathrm{bugs} /$ plant) compared with that on single row spacing which ranged 0 to 3.67 bugs/plant. Moreover, general mean of population density of mealybugs (14.53 bugs/plant) on double row was significantly higher than that on single row spacing (1.83 bugs/plant). In line with this mealybugpopulation development, mean numbers of fire ants caught on baited-sticky traps were ranged from 0 to 8.53 ants/trap on single row versus 0 to 23.57 ants/trap on double row spacing pattern. The general mean number of captured ants (12.73 ants/trap) on double row was significantly higher compared with that on single row spacing (5.55 ants/trap). It appears that the patterns of population densities of mealybugs are closely related to that of fire ants that act as attendant species on two pineapple row spacing.
\end{abstract}

Key words: association, Dysmicoccus brevipes, fire ant, pineapple mealy bug, plant-row spacing, Solenopsis sp.

\section{PENDAHULUAN}

Salah satu hama penting yang menyerang pertanaman tebu yang dapat menimbulkan kerugian yang besar adalah kutu dompolan, Dysmicoccus brevipes (Ckll.) (Homoptera: Pseudococcidae). Pada umumnya, kutu dompolan hidup dalam koloni $( \pm 20$ ekor/koloni) pada bagian bawah tanaman terutama bagian pangkal batang dan akar. Namun pada populasi tinggi, hama ini juga menyerang pangkal daun dan buah yang dapat mengakibatkan penurunan produksi. Dalam perkembangannya, kutu dompolan dapat menghasilkan embun madu (cairan manis dan kental) yang dapat berfungsi sebagai media

pertumbuhan cendawan, Capnodium sp., yang dapat menghambat proses fotosintesa tanaman (Batholomew et al., 2002; Collins, 1960; Johnson, 1979; Pracaya, 1982). Selain itu, kutu dompolan dapat juga berperan sebagai vektor virus (closterovirus) penyebab penyakit layu (pineapple wilt disease) dan penyakit virus lain yang disebut green spot (Broadley et al., 1993; Hill \& Waller, 1994; Kalshoven, 1981).
Kutu dompolan hidup bersimbiosis dengan semut api, Solenopsis sp., (Hymenoptera: Formicidae). Semut mendapatkan embun madu yang dihasilkan oleh kutu dompolan dengan cara memukulmukul abdomen kutu sehingga merangsang kutu untuk mengeluarkan embun madu. Sementara itu, kutu dompolan juga mendapat manfaat dari koloni semut, semut melindungi hama kutu dompolan dari musuh alaminya seperti parasitoid dan predator serta membantu penyebaran kutu dompolan dari satu tanaman ke tanaman lain (Mau \& Kessing, 1992). Ada tiga jenis semut yang diketahui bersimbiosis dengan populasi kutu dompolan di Hawaii, yaitu semut kepala besar, Pheidole megacephala (L.); semut Argentina, Iridomyrmex humilis (Mayr.); dan semut api, Solenopsis geminata Fab. Var. rufa (Johnson, 1979; Mau \& Kessing, 1992).

Beberapa faktor dapat mempengaruhi perkembangan populasi kutu dompolan dan juga spesies yang hidup berasosiasi dengannya yaitu semut api. Secara umum telah diketahui bahwa perkembangan populasi suatu spesies pada suatu

${ }^{1}$ Dosen Jurusan Proteksi Tanaman, Fakultas Pertanian, Universitas Lampung 
pertanaman tergantung pada stadia pertumbuhan tanaman, jumlah tanaman, dan cara bertanam (Bach, 1984; Hartman et al., 1981; Pimentel, 1961; Rohrbach, 1990). Di perkebunan nenas milik PT Great Giant Pineapple, cara tanam yang digunakan umumnya adalah sistem baris ganda (double row). Pada dasarnya penerapan cara tanam tersebut bertujuan untuk meningkatkan populasi tanaman yang akhirnya dapat meningkatkan produksi nenas. Pemahaman tentang cara perkembangan populasi suatu hama dan juga spesies yang hidup berasosiasi dengannya merupakan informasi penting dalam rangka pengelolaan dan pengendalian suatu hama. Penelitian ini bertujuan untuk mengetahui keeratan hubungan antara hama kutu dompolan dengan semut api pada dua cara bertanam nenas (baris tunggal = single row dan lajur ganda $=$ double row) dengan empat periode pertumbuhan tanaman nenas.

\section{METODE PENELITIAN}

Penelitian dilaksanakan di perkebunan nenas milik PT Great Giant Pineapple (GGP), Kecamatan Terbanggi Besar, Kabupaten Lampung Tengah. Penelitian berlangsung dari bulan April sampai bulan Oktober 2004. Penelitian dilakukan dengan metode survei (sigi). Survei awal telah dilakukan untuk menentukan petak percobaan yaitu areal pertanaman yang ditanami dengan dua jenis cara tanam satu baris per bedengan (single row) dan dua baris per bedengan (double row) dengan empat stadia pertumbuhan yaitu pertanaman umur 3, 7, 11 dan 17 bulan.
Sebanyak 24 petak percobaan (2 cara tanam $\mathrm{x}$ 4 stadia pertumbuhan $\times 3$ ulangan) masing-masing berukuran $10 \mathrm{~m}$ x $30 \mathrm{~m}$ dengan jarak antarpetak adalah $100 \mathrm{~m}$ telah diplot dan diberi label. Dua cara pertanaman yaitu baris tunggal (single row) dan baris ganda (double row) telah dipilih secara seksama. Pada cara tanam baris tunggal, setiap bedengan hanya terdiri dari satu baris tanaman. Jarak antartanaman dalam satu baris $20 \mathrm{~cm}$, dan jarak antarbedengan 50 $\mathrm{cm}$ (Gambar 1). Sedangkan pada cara tanam baris ganda, tiap bedengan terdiri dari dua baris tanaman. Jarak antartanaman dalam satu baris $25 \mathrm{~cm}$, dan jarak antarbedengan $60 \mathrm{~cm}$ (Gambar 2). Empat stadia pertumbuhan (3, 7, 11, and 17 bulan setelah tanam) telah dipilih secara sistematik untuk setiap cara tanam. Setiap cara tanam untuk setiap stadia pertumbuhan telah diulang tiga kali. Langkah selanjutnya adalah memeriksa dan menandai semua tanaman nenas yang terserang hama kutu kutu dompolan dan sebanyak 10 tanaman yang terserang kutu dompolan telah dipilih secara acak pada setiap plot. Masing-masing tanaman terok kemudian diberi label.

Pengamatan populasi kutu dompolan dilakukan dengan cara memeriksa dan menghitung jumlah kutu yang terdapat pada tanaman nenas. Tanaman terok dicabut perlahan-lahan, kemudian kutu yang terdapat di daerah perakaran dihitung dengan bantuan kuas halus. Untuk menghitung kutu dompolan yang terdapat pada pangkal daun dilakukan dengan cara membuka pelepah daun nenas satu persatu, begitu juga pada bagian buah.

Sedangkan pengamatan populasi semut dilakukan dengan memasang perangkap berumpan

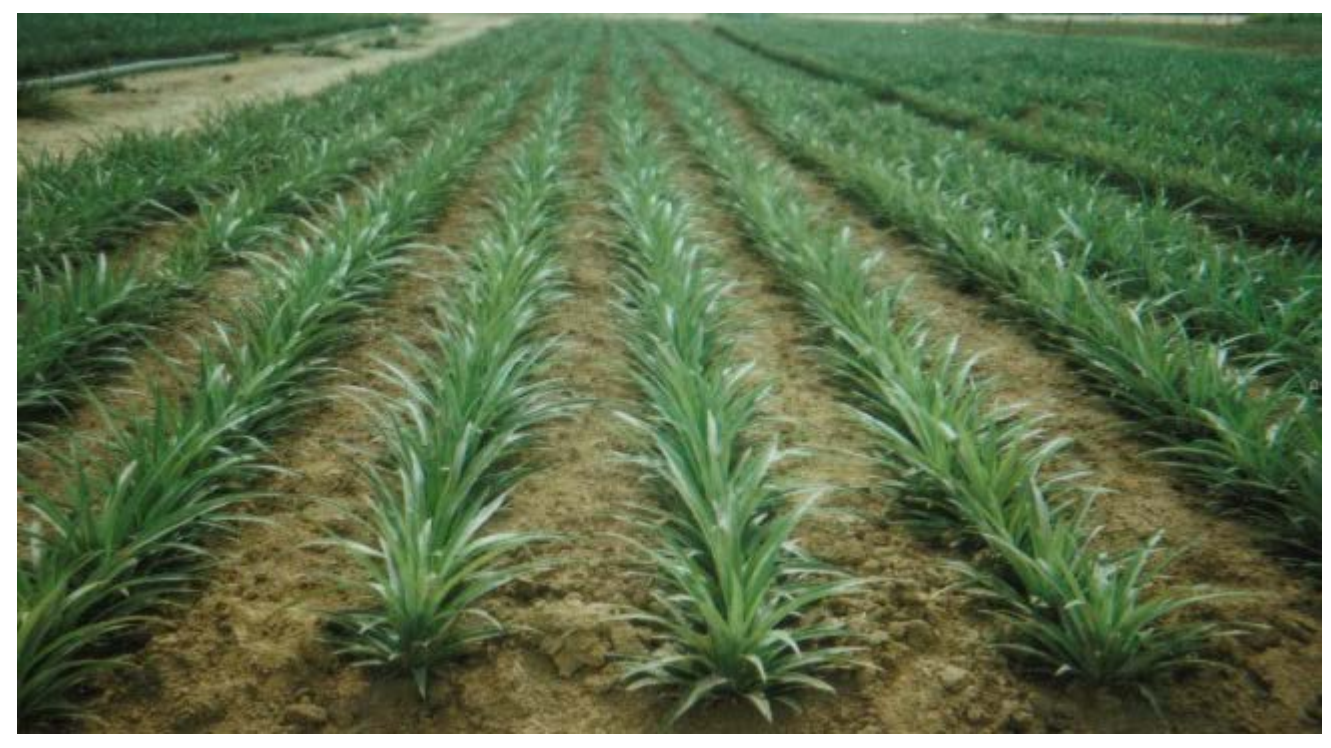

Gambar 1. Cara pertanaman nenas baris tunggal (single row) 


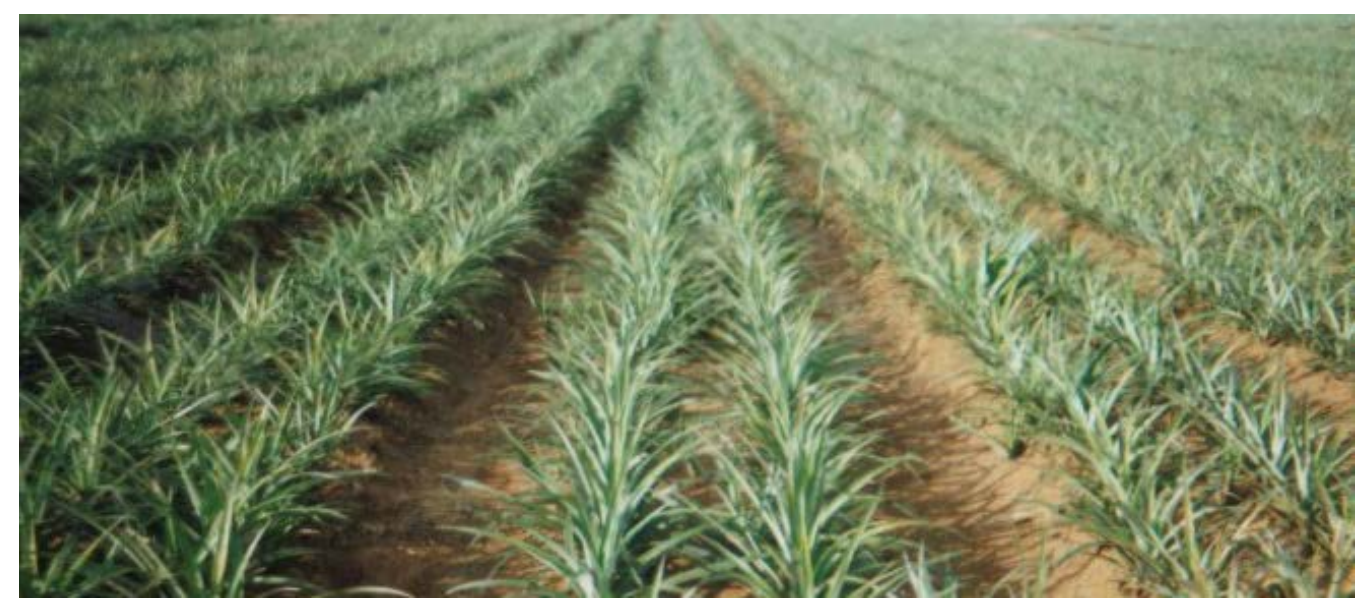

Gambar 2. Cara pertanaman nenas baris ganda (double row)

(baited traps) di sekitar sarang semut. Perangkap semut dibuat dengan cara mencampur tepung sagu dan bumbu masak dengan perbandingan $0,5 \mathrm{~kg}$ tepung sagu, $100 \mathrm{gr}$ bumbu masak, dan $60 \mathrm{ml}$ air. Campuran ini kemudian dimasak hingga matang (berbentuk lem). Salah satu bagian ujung (bagian atas) ajir bambu setinggi $10 \mathrm{~cm}$ diolesi dengan lem-umpan tersebut. Pada setiap petak percobaan, 10 buah ajir bambu berumpan dipasang di sekitar sarang semut pada pagi hari. Pengamatan semut dilakukan satu jam setelah pemasangan ajir.

Data yang telah terkumpul yaitu populasi hama kutu dompolan dan semut api disusun dan ditampilkan dalam bentuk grafik. Analisis korelasi linear dengan menggunakan SAS Software (CORR Procedure) telah dilakukan untuk mengetahui keeratan hubungan kutu dompolan dan semut api. Sedangkan untuk mengetahui perbedaan kepadatan populasi kutu dompolan dan semut api pada dua cara tanam untuk masing-masing stadia pertumbuhan dilakukan dengan analisis sidik ragam (ANOVA Procedure) juga dengan menggunakan perangkat pengolah data SAS System (SAS Institute Inc., 1989).

\section{HASIL DAN PEMBAHASAN}

Hasil pengamatan menunjukkan bahwa terdapat hubungan yang erat antara spesies kutu dompolan (Dysmicoccus brevipes) dan semut api (Solenopsis sp.) terutama pada akhir stadia pertumbuhan umur 11 bulan (fase pembungaan) dan 17 bulan (menjelang panen) pada cara tanam baris tunggal, dan pada umur 7, 11, dan 17 bulan pada baris ganda. Hasil analisis statistik menunjukkan nilai koefisien korelasi antara kutu dompolan dan semut api tertinggi (0.91) terdapat pada cara pertanaman baris ganda umur 17 bulan dan nilai koefisien korelasi ini sangat nyata $(\mathrm{P}>|\mathrm{R}|=0.001$; Tabel 1$)$. Namun pada awal pertumbuhan (umur 3 bulan dan 7 bulan untuk cara tanam baris tunggal dan umur 3 bulan untuk cara tanam baris ganda), nilai koefisien korelasi tidak terdeteksi, hal ini disebabkan karena populasi adalah 0 (Tabel 1). Hasil pengamatan ini menunjukkan bahwa hubungan antara kutu dompolan dan semut api semakin erat untuk kedua cara bertanam nenas yang diamati pada akhir pertumbuhan (pada saat populasi tertinggi).

Tabel 1. Nilai koefisien korelasi (Rho = r-hit) antara populasi kutu dompolan Dysmicoccus brevipes dan semut api Solenopsis sp. pada dua cara bertanam nenas dengan empat stadia pertumbuhan

\begin{tabular}{|c|c|c|c|c|c|c|}
\hline \multirow{3}{*}{$\begin{array}{c}\text { Umur } \\
\text { Tanaman (bulan) }\end{array}$} & \multicolumn{6}{|c|}{ Koefisien korelasi dan peluang nyata pada dua cara tanam } \\
\hline & \multicolumn{3}{|c|}{ Baris tunggal } & \multicolumn{3}{|c|}{ Baris ganda } \\
\hline & Rho & $\operatorname{Pr}>|\mathrm{R}|^{1)}$ & $\mathrm{n}$ & Rho & $\mathrm{P}>|\mathrm{R}|^{1)}$ & $\mathrm{n}$ \\
\hline 3 & - & - & 30 & - & - & 30 \\
\hline 7 & - & - & 30 & 0,6343 & 0,0108 & 30 \\
\hline 11 & 0,6403 & 0,0209 & 30 & 0,7490 & 0,0007 & 30 \\
\hline 17 & 0,8151 & 0,0002 & 30 & 0,9100 & 0,0001 & 30 \\
\hline
\end{tabular}

1) Peluang nyata untuk Ho: Rho = 0 berdasarkan analisis korelasi (PROC CORR; SAS Institute Inc., 1989). 
Berdasarkan hasil pengamatan pada pertanaman nenas terlihat bahwa kehadiran kutu dompolan ternyata diikuti pula oleh kehadiran beberapa jenis semut terutama semut api (Solenopsis sp.). Hal ini merupakan indikasi adanya hubungan mutualistik antara kutu dompolan dengan semut api. Hasil yang relatif sama juga ditemukan oleh Way (1963) dan Tedders et al. (1990) yang melaporkan bahwa semut api hidup bersimbiosis dengan spesies kutu Homoptera yang menghasilkan embun madu. Semut akan memakan embun madu yang dihasilkan oleh kutu dompolan. Selain itu, semut juga melindungi kutu dari musuh alaminya dan membantu penyebaran kutu ke tanaman di sekitarnya (Johnson, 1979). Pentingnya peranan semut api terhadap perkembangan populasi kutu dompolan mengakibatkan pengendalian hama kutu dompolan dan penyakit layu nenas difokuskan pada pengendalian semut yang bersimbiosis dengan kutu dompolan (Mau \& Kessing, 1992; Hartmann et al.,1981).

Kepadatan populasi hama kutu dompolan pada cara bertanam baris ganda cenderung semakin meningkat (berkisar antara 0 hingga 23,57 ekor/tanaman) sejalan dengan waktu pertumbuhan tanaman. Cara perkembangan populasi yang sama juga terjadi pada pertanaman nenas dengan baris tunggal, kepadatan populasi meningkat dari 0 menjadi 3,67 ekor/tanaman. Namun demikian, kepadatan populasi kutu dompolan pada pertanaman baris tungggal selalu lebih rendah dibandingkan pertanaman nenas baris ganda (Gambar 3).
Perbedaan kepadatan populasi kutu dompolan pada dua cara bertanam yang terlihat pada Gambar 3 juga dipertegas oleh hasil analisis statistik yang menunjukkan bahwa rerata umum (rerata dari 4 stadia pertumbuhan) kutu dompolan (14,53 ekor/tanaman) pada pertanaman baris tunggal nyata lebih rendah dibandingkan dengan pada pertanaman nenas baris ganda (1,83 ekor/tanaman) (Nilai $\mathrm{F}=8,46$ dan $\mathrm{P}>\mathrm{F}$ =0,0155; Tabel 2).

Seperti halnya kutu dompolan, kepadatan populasi semut api, Solenopsis sp. pada pertanaman nenas dengan cara bertanam baris tunggal yang berkisar dari 0 sampai 8,53 ekor/perangkap selalu lebih rendah dibandingkan dengan pada cara bertanam baris ganda yang berkisar antara 0 sampai 23,57 ekor/perangkap (Gambar 4). Selanjutnya hasil analisis menunjukkan bahwa rerata umum jumlah semut yang terperangkap pada ajir berumpan pada cara tanam baris tunggal (5,55 ekor/perangkap) nyata lebih rendah dibandingkan dengan pada cara bertanam baris ganda (12,73 ekor/perangkap) (Nilai $\mathrm{F}=6,88$; $\mathrm{Pr}>\mathrm{F}$ =0,027; Tabel 2). Hasil percobaan ini menunjukkan bahwa cara bertanam dapat mempengaruhi kepadatan populasi hama kutu dompolan dan juga semut api yang hidup berasosiasi pada pertanaman nenas. Hasil ini didukung oleh Bach (1984) dan Pimentel (1961) yang menemukan bahwa cara bertanam dapat mempengaruhi kepadatan populasi serangga herbivor dan juga spesies yang berasosiasi dengannya. Dengan demikian terdapat indikasi bahwa cara tanam baris ganda yang umum digunakan di pertanaman nenas (karena dapat meningkatkan populasi tanaman

Tabel 2. Rerata umum kepadatan populasi kutu dompolan dan semut yang hidup beasosiasi pada dua cara bertanam nenas

\begin{tabular}{lcc}
\hline Cara tanam & $\begin{array}{c}\text { Kutu dompolan } \\
(\text { ekor/tanaman })^{1)}\end{array}$ & Semut (ekor/perangkap) \\
\hline Baris tunggal & $1,83 \mathrm{~b}^{2)}$ & $5,55 \mathrm{~b}^{2)}$ \\
Baris ganda & $14,53 \mathrm{a}$ & $12,73 \mathrm{a}$ \\
\hline Nilai F & 8,46 & 6,88 \\
Pr $>\mathrm{F}$ & 0,015 & 0,027 \\
\hline
\end{tabular}

${ }^{1)}$ Rerata umum adalah rerata dari empat stadia pertumbuhan

2) Nilai tengah pada satu kolom yang diikuti oleh huruf yang sama tidak berbeda nyata berdasarkan Uji F (PROC GLM; SAS Institute Inc., 1989). 


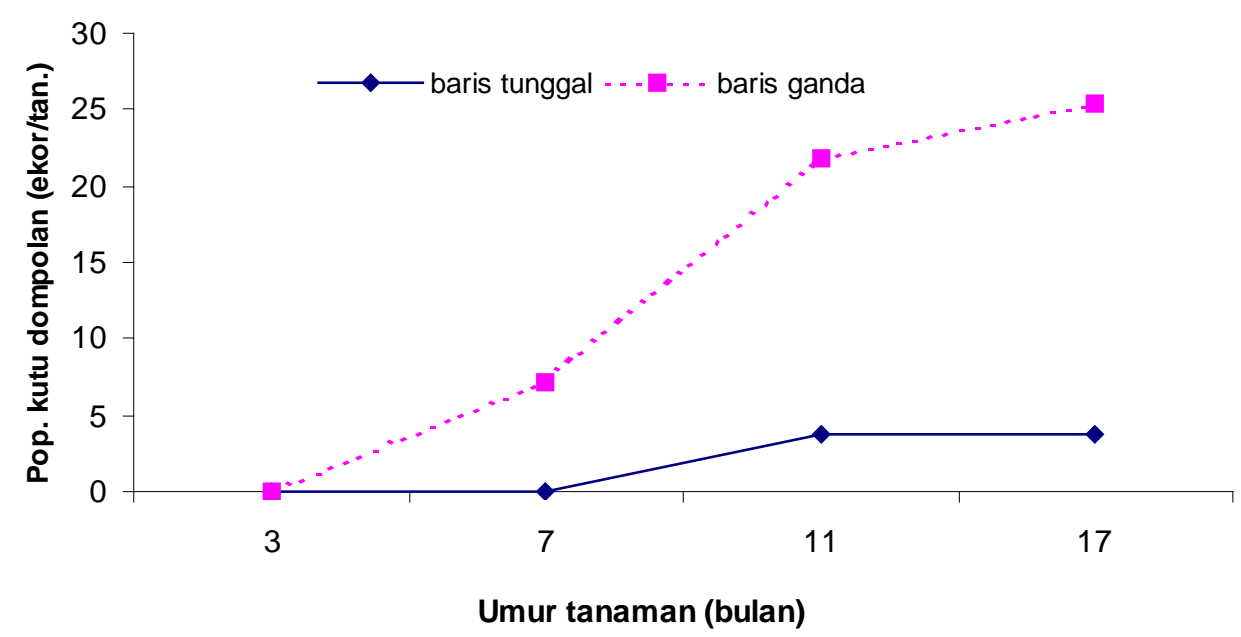

Gambar 3. Kepadatan populasi populasi kutu dompolan (ekor/tanaman) dua cara bertanam nenas (baris tunggal dan ganda) dengan stadia umur tanaman yang berbeda

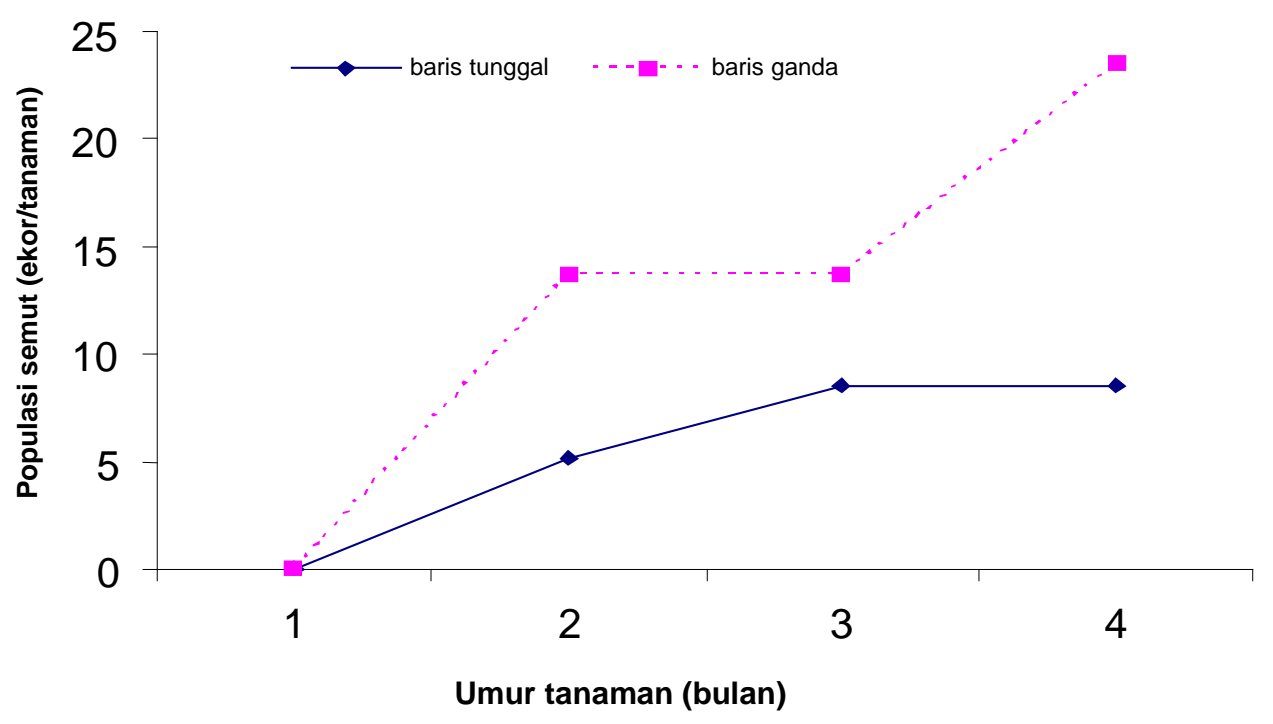

Gambar 4. Kepadatan populasi semut api (ekor/perangkap ) pada dua cara bertanam nenas (baris tunggal dan ganda) dengan stadia umur tanaman yang berbeda 
sekaligus produksi) ternyata juga rentan terhadap serangan hama kutu dompolan.

\section{SIMPULAN}

Berdasarkan hasil pengamatan lapang terbukti bahwa hama kutu dompolan (Dysmicoccus brevipes) mempunyai hubungan yang erat (koefisien korelasi nyata) dengan semut api (Solenopsis sp.) pada dua cara bertanam nenas (baris tunggal dan baris ganda) terutama pada akhir stadia pertumbuhan (umur 11 bulan $=$ fase pembungaan dan 17 bulan = menjelang panen. Rerata umum kepadatan populasi kutu dompolan (14,53 ekor/tanaman) pada cara bertanam baris ganda nyata lebih tinggi dibandingkan yang ditanaman secara baris tunggal $(1,83$ ekor/tanaman). Sejalan dengan populasi kutu dompolan, rerata umum semut api yang terperangkap pada ajir-berumpan (12,73 ekor/perangkap) nyata lebih tinggi dibandingkan dengan cara bertanam baris tunggal (5,55 semut/perangkap). Hasil penelitian ini menunjukkan bahwa hubungan hama kutu dompolan dengan semut api tertinggi terdapat pada cara tanam baris ganda.

\section{SANWACANA}

Penulis mengucapkan terimakasih kepada Bapak Basuki dan Ibu Sumaratri (Staf R \& D PT Great Giant Pineapple (GGP) atas bantuan teknis dan fasilitas. Ucapan terima kasih juga ditujukan kepada Bapak Dr. Ir Purnomo, M.S (Dosen Jurusan Proteksi FP Unila) dan Saudara Roma Subangkit H Gultom (alumnus FP Unila) yang membantu dalam pelaksanaan penelitian ini.

\section{DAFTAR PUSTAKA}

Bach, C.E. 1984. The spatial pattern and herbivore population dynamics: plant factors affecting the movement patterns of a tropical cucurbits specialist (Acalymna innubum). Ecology $65: 175-190$

Bartholomew, D. P., R. E. Paull, \& K.G. Rohrback. 2002. The Pineapple: Botany, Production and Uses. University of Hawaii at Manoa Honolulu USA. CABI Publishing. New York.
Broadley, R.H., R.C. Wassman, \& E. Sinclair. 1993. Pineapple Pests Disorders. Dept. of Primary Industries, Queensland.

Collins, J. L. 1960. The Pineapple: Botany, Cultivation, and Utilization. Interscience Publishers Inc. New York.

Hartmann, H. T., William J. Flocker, \& A. M. Kofranek. 1981. Plant Science: Growth, Development, and Utilization of Cultivated Plants. Prentice-Hall, Inc. New Jersey.

Hill, D.S. \& J.M. Waller. 1994. Pests and Diseases of Tropical Crops. Longman. England.

Johnson, M. W. 1979. Sustainable Pineapple Mealybug Management Via Augmentative Biological Control. Department of Entomology, University of Hawaii. Manoa, 3050 Maile Way Honolulu.

Kalshoven, L. G. E. 1981. The Pest of Crops in Indonesia. Revised and Translated By P. A. Van der laan. Ichtiar Baru - Van Hoeve. Jakarta.

Kranz, J., H.Schmutterer, \& W. Koch. 1978. Disease, Pest and Weeds in Tropical Crops. John Wiley \& Sons. New York.

Mau, R. F. L. \& J. L. M. Kessing 1992. Dysmicoccus brevipes (Cockerell). Department of Entomology. Honolulu, Hawaii.

Pimentel, D. 1961. The influence of plant spatial patterns on insect populations. Ann. Entomol. Soc. Am. 54: 61-69

Pracaya. 1982. Bertanam Nenas. Penebar Swadaya. Jakarta.

Rohrbach, K. G. 1990. Pineapple: The Plant and Its Culture. Hawaii Agricultural Experiment Station. Hawai Institute of Tropical Agriculture and Human Resources. University of Hawaii at Manoa.

SAS Institute Inc. 1989. SAS/SAT User's Guide. Version 6, Fourth Edition. SAS Institute, Cary, N.C. 
Tedders, C.,C. Reilly, \& B.W. Wood, 1990. Behavior of Solenopsis invicta (Hymenoptera: Formicidae) in Pecan Orchards. Environ. Entomol. 19(1): 44-53.
Way, M.J. 1963. Mutualism between ants and honeydew producing Homoptera. Annu. Rev. Entomol. 8:307-344 
